THE REPUGNANT CONCLUSION 
LIBRARY OF ETHICS AND APPLIED PHILOSOPHY

VOLUME 15

Managing Editor:

Govert A. den Hartogh, University of Amsterdam, The Netherlands

The titles published in this series are listed at the end of this volume. 


\section{THE REPUGNANT CONCLUSION}

Essays on Population Ethics

Edited by

JESPER RYBERG

University of Roskilde,

Denmark

and

TORBJÖRN TÄNNSJÖ

Stockholm University,

Sweden

KLUWER ACADEMIC PUBLISHERS

DORDRECHT / BOSTON / LONDON 
A C.I.P. Catalogue record for this book is available from the Library of Congress.

ISBN 1-4020-2472-X (HB)

ISBN 1-4020-2473-8 (e-book)

Published by Kluwer Academic Publishers,

P.O. Box 17, 3300 AA Dordrecht, The Netherlands.

Sold and distributed in North, Central and South America

by Kluwer Academic Publishers,

101 Philip Drive, Norwell, MA 02061, U.S.A.

In all other countries, sold and distributed

by Kluwer Academic Publishers,

P.O. Box 322, 3300 AH Dordrecht, The Netherlands.

Printed on acid-free paper

All Rights Reserved

(C) 2004 Kluwer Academic Publishers

No part of this work may be reproduced, stored in a retrieval system, or transmitted

in any form or by any means, electronic, mechanical, photocopying, microfilming, recording or otherwise, without written permission from the Publisher, with the exception of any material supplied specifically for the purpose of being entered and executed on a computer system, for exclusive use by the purchaser of the work.

Printed in the Netherlands. 


\section{CONTENTS}

INTRODUCTION

1

Jesper Ryberg and Torbjörn Tännsjö

OVERPOPULATION AND THE QUALITY OF LIFE

7

Derek Parfit

TWO PARFIT PUZZLES

Tim Mulgan

CRITICAL-LEVEL POPULATION PRINCIPLES AND

THE REPUGNANT CONCLUSION

Charles Blackorby, Walter Bossert and David Donaldson

O REPUGNANCE, WHERE IS THY STING?

61

Clark Wolf

RESOLVING THE REPUGNANT CONCLUSION

81

Tyler Cowen

PERSON-BASED CONSEQUENTIALISM AND THE

99 PROCREATION OBLIGATION

Melinda A. Roberts

PERSON-AFFECTING MORALITIES

Nils Holtug

REPUGNANCE OR INTRANSITIVITY:

A REPUGNANT BUT FORCED CHOICE

Stuart Rachels

THE ROOT OF THE REPUGNANT CONCLUSION AND

ITS REBUTTAL

Ingmar Persson

THE PARADOXES OF FUTURE GENERATIONS

AND NORMATIVE THEORY

Gustaf Arrhenius

WHY WE OUGHT TO ACCEPT THE REPUGNANT CONCLUSION

Torbjörn Tännsjö

THE REPUGNANT CONCLUSION AND WORTHWHILE LIVING

Jesper Ryberg

POSTSCRIPT

Derek Parfit

INDEX OF NAMES 